\title{
Histopathological and immunohistochemical aspects of American cutaneous leishmaniasis before and after different treatments*
}

Aspectos histopatológicos e imuno-histoquímicos da leishmaniose tegumentar americana antes e depois de diferentes tratamentos

\author{
Agostinho Gonçalves Viana ${ }^{1}$ \\ Carlos Alberto de Carvalho Fraga ${ }^{3}$ \\ Patrícia Luciana Batista Domingos ${ }^{1}$ \\ Alfredo Maurício Batista de Paula ${ }^{6}$
}

\author{
Wilson Mayrink ${ }^{2}$ \\ Luciana Maria Silva ${ }^{4}$ \\ Paulo Rogério Ferreti Bonan ${ }^{5}$ \\ Ana Cristina de Carvalho Botelho ${ }^{6}$
}

\begin{abstract}
BaCKGRound: The histopathology and immune responses of the healing process of leishmaniasis are still poorly studied.

OвJECTIVES: This study aimed to examine the histopathological and immunological aspects of lesions of patients with cutaneous leishmaniasis before and after different therapeutic methods.

MEтHоDS: We studied 23 individuals grouped according to the treatments: Glucantime, Glucantime + Leishvacin and Glucantime + Leishvacin associated with Bacillus Calmette-Guerin. For analysis of the histopathological changes present in the dermis and epidermis, histological sections were stained with hematoxylin and eosin. The samples were immunostained before and after treatment to analyze the expression of interferon (IFN)- $\gamma$, interleukin (IL) 12, IL-10 and IL-4. RESULTS: Before treatment the presence of intense infiltrates of mononuclear cells was noticed and after treatment, even with a diagnosis of clinical cure, the subjects still showed a moderate inflammatory process. In the immunohistochemical analyses, we noticed a difference between the cytokines, with increased expression of cytokines IFN- $\gamma$ and IL-12 compared to IL10 and IL- 4 , both before and after treatment and, comparatively, the difference in this expression was more intense before treatment. However, the cytokine expression analyzed by treatment group showed no statistically significant difference.

Conclusion: We conclude that a clinical cure does not always coincide with the histopathological one, and that before treatment there is a predominance of Th1 cytokines. In terms of treatment type, there was no difference in the progression of healing for all the three types of treatment, indicating their clinical equivalence.
\end{abstract}

Keywords: Cytokines; Histology; Immunohistochemistry; Leishmaniasis; Leishmaniasis, cutaneous

Resumo: Fundamentos: A histopatologia e as respostas imunológicas do processo de cura da leishmaniose são ainda pouco estudadas.

OBjetivos: Este estudo teve como objetivo avaliar os aspectos histopatológicos e imunológicos das lesões de pacientes com leishmaniose tegumentar, antes e após diferentes métodos terapêuticos.

MÉTODOS: Foram estudados 23 indivíduos agrupados de acordo com os tratamentos: Glucantime, Glucantime + Leishvacin e Glucantime + Leishvacin associado com Bacilo Calmette-Guerin. Para a análise das alterações histopatológicas presentes na derme e epiderme, cortes histológicos foram corados com hematoxilina e eosina. Para avaliar a expressão de interferon (IFN)- $\gamma$, interleucina (IL) 12, IL-10 e IL-4 foi utilizada a técnica de imuno-histoquímica antes e após o tratamento.

RESUlTADOS: Antes do tratamento houve um intenso infiltrado de células mononucleares, após o tratamento, mesmo com um diagnóstico de cura clínica, apresentou-se ainda um moderado processo inflamatório. Na análise imuno-histoquímica, notamos uma diferença entre as citocinas, com expressão aumentada de citocinas IFN- $\gamma$ e IL-12 em comparação com IL-10 e IL-4 tanto antes quanto depois do tratamento, e comparativamente, a diferença nesta expressão mostrou-se mais intensa antes do tratamento. No entanto, a expressão das citocinas analisadas por grupo de tratamento não mostraram diferenças estatisticamente significativas.

Conclusão: Concluímos que uma cura clínica nem sempre coincide com a cura histopatológica, e que antes do tratamento há uma predominância de citocinas Th1. Para os tratamentos, não houve diferença na progressão da cura para todos os três tipos de tratamento, indicando a equivalência clínica dos tratamentos.

Palavras-chave: Citocinas; Histologia; Imunoistoquímica; Leishmaniose; Leishmaniose cutânea

Received on 17.10.2011.

Approved by the Advisory Board and accepted for publication on 08.04.2012.

* Work performed at the Health Reserch Laboratory, Hospital Universitário Clemente de Faria, Universidade Estadual de Montes Claros (UNIMONTES) - Montes Claros (MG), Brazil.

Financial funding: None

Conflict of interest: None

Graduation - Master Candidate in Health Sciences by the Universidade Estadual de Montes Claros (UNIMONTES) - Montes Claros (MG), Brazil.

$\mathrm{PhD}$ - Teacher at the Parasitology Department of the Universidade Federal de Minas Gerais (UNIMONTES) - Montes Claros (MG), Brazil.

Master - PhD Candidate in Health Sciences by the Universidade Estadual de Montes Claros (UNIMONTES) - Montes Claros (MG), Brazil.

$\mathrm{PhD}$ - Researcher at the Centro de Pesquisa e Desenvolvimento Fundação Ezequiel Dias (FUNED) - Belo Horizonte (MG), Brazil.

PhD - Teacher at the Universidade Federal da Paraíba, (UFPB) - João Pessoa (PB), Brazil.

PhD - Teacher of the Post-Graduation Program in Health Sciences by the Universidade Estadual de Montes Claros (UNIMONTES) - Montes Claros (MG), Brazil. 


\section{INTRODUCTION}

Leishmaniases are diseases caused by various species of protozoa of the genus Leishmania, which affect humans and different animal species and might present different clinical forms, depending on the species involved and the relationship of the parasite with its host. ${ }^{1}$ Transmission occurs through the bite of infected female flies of the subfamily Phlebotominae, belonging to the genus Lutzomyia. ${ }^{2}$ It is estimated that 12 million people are currently infected with leishmaniasis and the World Health Organization (WHO) considers that 350 million of people are at risk of contracting this disease. ${ }^{3}$ In Brazil, American cutaneous leishmaniasis (ACL) represents a public health problem and its incidence has increased significantly. ${ }^{4}$

Pentavalent antimony was introduced as a substitute for the tartar emetic, and is still used nowadays. Although pentavalent antimony is less toxic, it is still associated with important side effect and its use is not encouraged in specific cases. Scholars are paying attention to new therapeutic strategies using Leishmania antigens based on the principle of immunological stimulation. ${ }^{5}$ Mayrink et al. conducted a study to assess the efficacy of treatment with chemotherapy, immunotherapy and a combination of both, and it was noted that the association of antimony with immunotherapy had the same effect as the standard treatment whilst reducing the amount of salt used, the average treatment duration and the collateral effects. ${ }^{6}$

The histopathological study of ACL emerged with the identification of this disease in Brazil. It is known that the histopathological diagnosis varies from an inflammatory infiltrate of mononuclear cells and neutrophils, to granulomatous reactions with or without necrosis. ${ }^{7}$ Studies have attempted to establish the importance of histopathology in the diagnosis of ACL; however, different morphological findings have been found. ${ }^{8,9}$

In an attempt to establish the importance of the immune response an experimental model with different species of Leishmania has been used; however, it is accepted that the Thelper 1 (Th1) response is associated with the both parasite control and pathology, whereas the T helper 2 (Th2) response is associated with disease susceptibility. ${ }^{10}$ However, it is assumed that infection with Leishmania induces a mixture of Th1 and Th2 responses. ${ }^{11}$

The susceptibility or resistance of the host depends on several factors such as the species of parasite and vector, and the genetic and immunological conditions of the host. ${ }^{12}$ Leishmania infection has been shown to be accompanied by a down-regulation in induced Th1 cytokine secretion interleukin (IL)-12 and interferon (IFN) $-\gamma$ with a simultaneous increase in the production of Th2 cytokines interleukin (IL)-4, IL5, and IL-10, suggesting a generalized imbalance in lymphocyte function. It has been established that Th1 cytokines promote macrophage activation and consequent destruction of Leishmania; in contrast, Th2type response is associated with the spread of leishmanial disease.

Our main objective was to evaluate the leishmanial healing process by histopathological analysis, including identifying the phenotypic profile of cytokines in lesions and scars before and after different therapeutic methods.

\section{MATERIAL AND METHODS \\ Population studied}

A retrospective study was performed with 23 individuals in a convenience sample, and the eligibility criteria for patients in the study were the positive diagnosis of ACL. These patients were attended in the clinic Paulo Araújo Magalhães, Caratinga, Minas Gerais, Brazil, between 1992 and 1993. The diagnosis was confirmed in all cases with a positive result of at least one of the tests, through biopsy for direct parasitological examination and Montenegro reaction. This study was approved by the Human Research Ethics Committee 1846/2010. The fragments were obtained by biopsy from lesions before the start of the treatment and from the scars 30-40 days after treatment, with clinical cure being determined by the total healing of the lesions.

The patients were divided into three groups depending on the treatment method:

Group I: Treatment: Glucantime. Eight patients: five females, three males. Seven of the patients had only one lesion, where six were on the leg and two on the thigh. The average age was 39 years, ranging from 13 to 64 . The average duration of the lesions was 118.5 days (range 38-210). Treatment: Glucantime was administered by intramuscular injection in daily doses of $1 \mathrm{~mL} / 5 \mathrm{~kg}$, not exceeding $10 \mathrm{~mL} /$ day, for 10 days, with treatment intervals of 10 days. The treatment period for this group was 30-110 days.

Group II: Treatment Leishvacin + Glucantime. Seven patients: two females and five males. The average age was 28 years, ranging from 12 to 42 . Most patients had only one lesion, whereas four patients had lesions on the leg, two patients on the thigh and one on the ankle. The average duration of the lesions was 75 days (range 45-90 days). The parasitological examinations were positive in all patients before treatment. Treatment: The vaccine Leishvacin was given by intramuscular injection according to Mayrink's scheme: Day $1-100 \mu \mathrm{L}$, Day $2-200 \mu \mathrm{L}$, Day $3-300$ $\mu \mathrm{L}$, Day $4-400 \mu \mathrm{L}$, and Days 5-10 - 500 $\mu \mathrm{L}$. This 
scheme was repeated after an interval of 10 days. ${ }^{14}$ Glucantime was administered via intramuscular injection in daily doses of $0.5 \mathrm{~mL} / 5 \mathrm{~kg}$ weight, not exceeding $5 \mathrm{~mL} / \mathrm{day}$, and given at the same time as the Leishvacin injection, also with an interval of 10 days between treatment sessions.

Group III: Treatment: Leishvacin + BCG (Bacillus Calmette-Guerin) associated with Glucantime. Eight patients: three females and five males. The average age was 36 years, ranging from 14 to 66 . The patients had only a localized lesion, where three patients had lesions on the leg, two patients on the forearm and two on the thigh and one patient on the shin. The average duration of the lesions was 90 days (range 30-180 days). The parasitological examinations were positive in all patients before treatment. Treatment: Leishvacin + BCG in a single dose by intradermal injection. Fifteen days later, Glucantime was given via intramuscular injection at a daily dose of $1 \mathrm{~mL} / 5 \mathrm{~kg}$ weight, not exceeding $10 \mathrm{~m}$ $\mathrm{L} /$ day, for 10 days, followed by a treatment interval of 10 days. The protein concentration of the vaccine was 600 $\mu \mathrm{g} / 0.2 \mathrm{~mL}$. The treatment period for this group varied between 43 and 108 days.

\section{Morphological analyses}

Each resected tissue specimen was fixed in formalin and embedded in paraffin. Histological sections of $4 \mu \mathrm{m}$ in thickness were stained with hematoxylin and eosin. The histopathological changes before and after the treatments were observed using an optical microscope (Olympus ${ }^{\circledR}$ ) at $\times 400$ magnification. The morphological parameters analyzed of the epidermis were acanthosis, dyskeratosis, papillomatosis, exocytosis, hyperkeratosis in the dermis, plasma exudative reaction and cellular exudative reaction, inflammatory infiltrate production (polymorphonuclear (PMNs), eosinophils and mononuclear cells), giant-cells, and a tendency to form granulomas.

\section{Immunohistochemistry}

Tissues were fixed and embedded in paraffin and the following antibodies were used: IFN- $\gamma$ (Santa Cruz H-145, dilution factor; 1:100), IL-12 (BD Biosciences C8.3, dilution factor; 1:50) IL-4 (BD Biosciences 8D4-8, dilution factor; 1:50) and IL-10 (BD Biosciences ES3-12G8, dilution factor; 1:50). The primary antibody was detected using the LSAB kit (Dako, Denmark), and the immunohistochemical method performed was described previously. ${ }^{15}$ As a positive control we used lymph node samples and the negative control of the reaction was obtained from the samples without primary antibody staining but submitted to the secondary antibody. The immunohistochemical expression of biomarkers was evaluated using an Olympus ${ }^{\circledR} \mathrm{BH} 2$ microscope $(\times 10$ ocular and $\times 40$ objective lenses). The percentage of immunohistochemically stained cells was determined from populations of 100-200 cells. The immunohistochemical analysis of the antigens investigated the percentage of positively stained cells. The immunohistochemical expression data are expressed as mean \pm standard deviation (mean $\pm \mathrm{sd}$ ) values.

\section{Statistical analysis}

The histopathological findings were compared to the treatment groups using the chi-square test. The Kolmogorov-Smirnov test was used to determine whether or not the distribution of continuous variables was normal. Analyses of the tissue immunolocalization of IFN- $\gamma$, IL-12, IL- 4 and IL-10 proteins assumed a nonparametrical distribution and a comparison between groups was performed using the Wilcoxon and MannWhitney statistical tests. All statistical analyses were performed using the statistical pack SPSS ${ }^{\circledR}$ (SPSS Inc., Chicago, IL, USA), version 13.0 for Windows ${ }^{\circledR}$; p values $<0.05$ were considered significant.

\section{RESULTS}

The results of the qualitative analyses before treatment were as follows: in the epidermis, there was a presence of accentuated acanthosis, papillomatosis and hyperkeratosis; in the dermis, we observed a predominance of intense exudative cellular reactions and the presence of mononuclear cells. After treatment, a decrease in the histopathological features of the epidermis was observed. In the dermis, however, the exudative cellular response was less intense and the presence of mononuclear cells persisted. The histopathological findings in the epidermis were decreased after the treatments (Tables 1 and 2). Taking these data, the pattern of decrease was significant, although some events persisted in one or more patients after the therapies. Figure 1 illustrates some of the histopathological characteristics.

The immunohistochemical expression pattern of IFN- $\gamma$, IL-12, IL- 4 and IL-10 before and after treatments is demonstrated in figure 2 . Regardless of the type of treatment, the cytokine expression in each group was analyzed before and after treatment. We observed a statistically significant difference $(p<0.05)$ between the expression of the cytokines (Graphic 1). We observed that the frequency of cells expressing IFN- $\gamma$, IL-12, IL- 4 and IL-10 proteins was lower after all treatments. However, there was no significant difference when we compared the before and after expression in each treatment group. In addition, quantitative analyses of cells expressing IFN- $\gamma$, IL-12, IL- 4 and IL-10 cytokines showed no significant differences when we compared the $\mathrm{G}, \mathrm{L}+\mathrm{G}$ and $\mathrm{L}+\mathrm{G}+\mathrm{BCG}$ treatments (Graphic 2). 
TABLE 1: Analysis of histopathological changes before and after treatment for each therapeutic group

\begin{tabular}{|c|c|c|c|c|c|c|c|c|c|}
\hline \multirow[t]{3}{*}{ Variables } & \multirow{3}{*}{$\begin{array}{l}\text { G } \\
\text { Before } \\
\mathbf{n}^{\circ}(\%)\end{array}$} & \multirow[b]{3}{*}{$\begin{array}{l}\text { After } \\
\text { no }^{\circ}(\%)\end{array}$} & \multirow[b]{3}{*}{$\begin{array}{l}\mathbf{p} \\
\mathbf{p}\end{array}$} & \multicolumn{5}{|c|}{ Treatments } & \multirow[b]{3}{*}{$\mathbf{p}$} \\
\hline & & & & $\mathbf{L}+\mathbf{G}$ & & $\mathbf{L}+\mathbf{G}+\mathbf{B C}$ & & \multirow[b]{2}{*}{ After } & \\
\hline & & & & $\begin{array}{l}\text { Before } \\
n^{\circ}(\%)\end{array}$ & $\begin{array}{l}\text { After } \\
n^{\circ}(\%)\end{array}$ & $\begin{array}{l}\mathbf{p} \\
\mathbf{n}^{\mathbf{o}}(\%)\end{array}$ & $\begin{array}{l}\text { Before } \\
n^{\circ}(\%)\end{array}$ & & \\
\hline \multicolumn{10}{|l|}{ Epiderm } \\
\hline Acanthosis & $8(100)$ & $3(37,5)$ & 0,007 & 7 (100) & $1(14,3)$ & 0,001 & $7(87,5)$ & $1(12,5)$ & 0,003 \\
\hline Exocytosis & $6(75,0)$ & 00,002 & $5(71,4)$ & $1(14,3)$ & 0,031 & $5(62,5)$ & 00,007 & & \\
\hline Papillomatosis & $8(100)$ & $3(37,5)$ & 0,007 & $7(100)$ & $2(28,6)$ & 0,005 & $6(75,0)$ & 0 & 0,002 \\
\hline Hyperkeratosis & $7(87,5)$ & $6(75,0)$ & N.s. & $7(100)$ & $4(57,1)$ & N.s. & $7(87,5)$ & $6(75,0)$ & N.s. \\
\hline Dyskeratosis & $7(87,5)$ & $1(12,5)$ & 0,003 & $5(71,4)$ & $1(14,3)$ & 0,003 & $4(50,0)$ & 0 & 0,021 \\
\hline \multicolumn{10}{|l|}{ Derm } \\
\hline TFG & $2(25,0)$ & $1(12,5)$ & N.s. & $1(14,3)$ & $2(28,6)$ & N.s. & $2(25,0)$ & $3(37,5)$ & N.s. \\
\hline Granuloma & 0 & $1(12,5)$ & N.s. & 0 & 0 & & 0 & 0 & \\
\hline
\end{tabular}

G: Glucantime; L+G: Leishvacin+Glucantime; L+G+BCG: Leishvacin+Glucantime+BCG;

TFG: tendency to formation of granuloma; N.s.: Not significant. Chi-square test.

TABLE 2: Histopathological characteristics before and after treatment for each therapeutic group

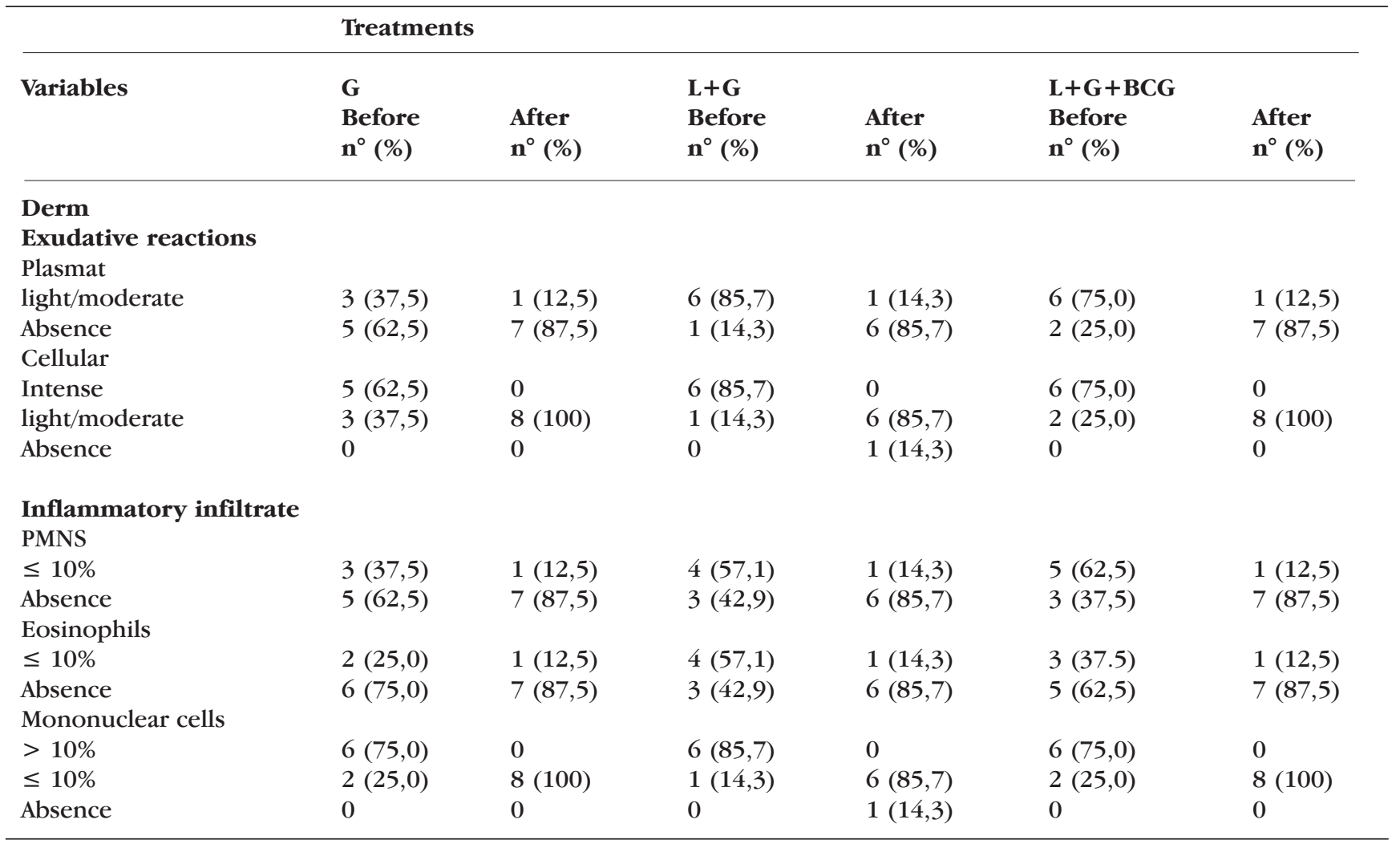

G: Glucantime; L+G: Leishvacin+Glucantime; L+G+BCG:

Leishvacin + Glucantime+BCG;

PMNS: polymorphonuclear. Analysis frequency.

\section{DISCUSSION}

In our study we evaluated the lesions and scars of patients with ACL. Assessments of the evolution of inflammation can contribute to the understanding of the healing process. We observed the presence of inflammatory cells in the lesions before treatment, whilst the samples from scars were characterized by the presence of a moderate to mild inflammation. The healing process could also be observed from the for- 

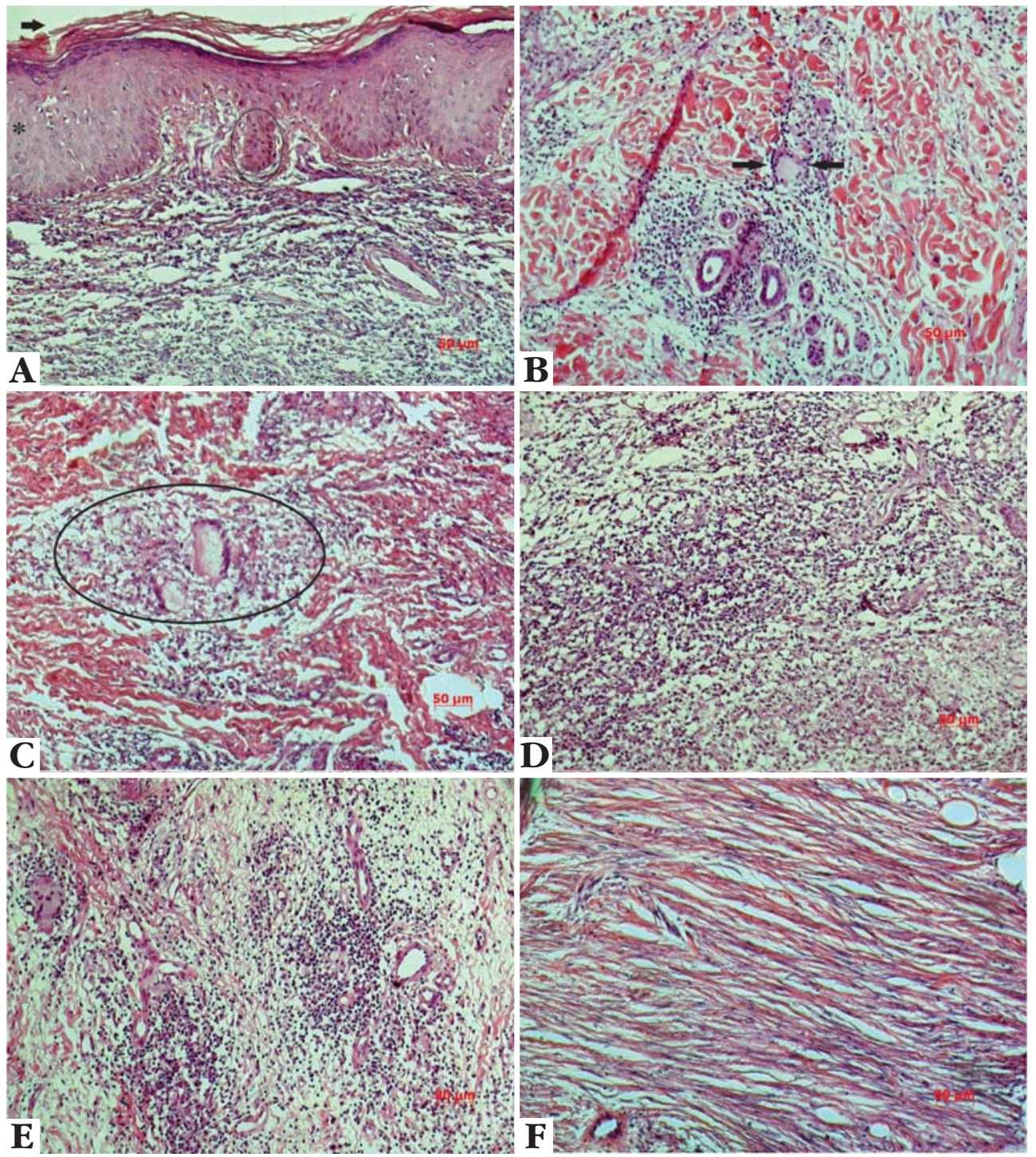

FIGURE 1: Representation of the some histopathological findings in leishmanial samples and their treatments. Fig. 1A-hyperkeratosis (arrow), papillomatosis (circle) and acanthosis (asterisk) (Glucantime); Fig. 1B - Langhans giant cell (between the arrows) (Leishvacin+Glucantime + BCG); Fig. 1C - granuloma (circle) (Glucantime); Fig. 1D- intense diffuse exsudation before treatment (Leishvacin+BCG); Fig 1E discrete inflammatory infiltration after treatment (Leishvacin +Glucantime+BCG); Fig. 1F fibers neoformation after treatment (Glucantime). Hematoxylin \& Eosin stain. Bar: $50 \mu \mathrm{m}$ mation of new collagen fibers, indicating a histopathological healing process.

These results highlight the importance of morphological analyses for gaining an understanding of the healing process, as discussed previously in an assessment of histopathology in human ACL cases. ${ }^{16}$ In this systematic study the authors found that evaluation of the histopathological scar is important for analyzing the healing process because by following the analysis of fragments from lesions and scars, obtained from patients diagnosed with $\mathrm{ACL}$, it was observed that the histopathological samples submitted both before and after treatment did not always correlate with the indications of a clinical cure. Besides, even after treatment, when the patients were considered clinically cured in some cases, an inflammatory process still persisted in skin lesions, despite com- plete healing of the lesion. Findings show that even after healing the parasite can be found. ${ }^{17,18}$ Then histopathological cure would be the absence of an inflammatory response.

The fundamental pathological changes are located in the dermis where the inflammatory infiltrates vary in intensity and composition according to the phase of infection. ${ }^{17}$ However, characteristics of the epidermis are important for distinguishing between lesions of other diseases. ${ }^{19}$

In some studies, biopsies were performed on the scars of patients treated for ACL where the presence of inflammatory cells was observed; some cases even presented a mild inflammatory process after 1-3 years of healing. ${ }^{18,20}$ In addition, the PCR procedure enabled the identification of leishmanial DNA, showing the persistence of the parasite after years of being 

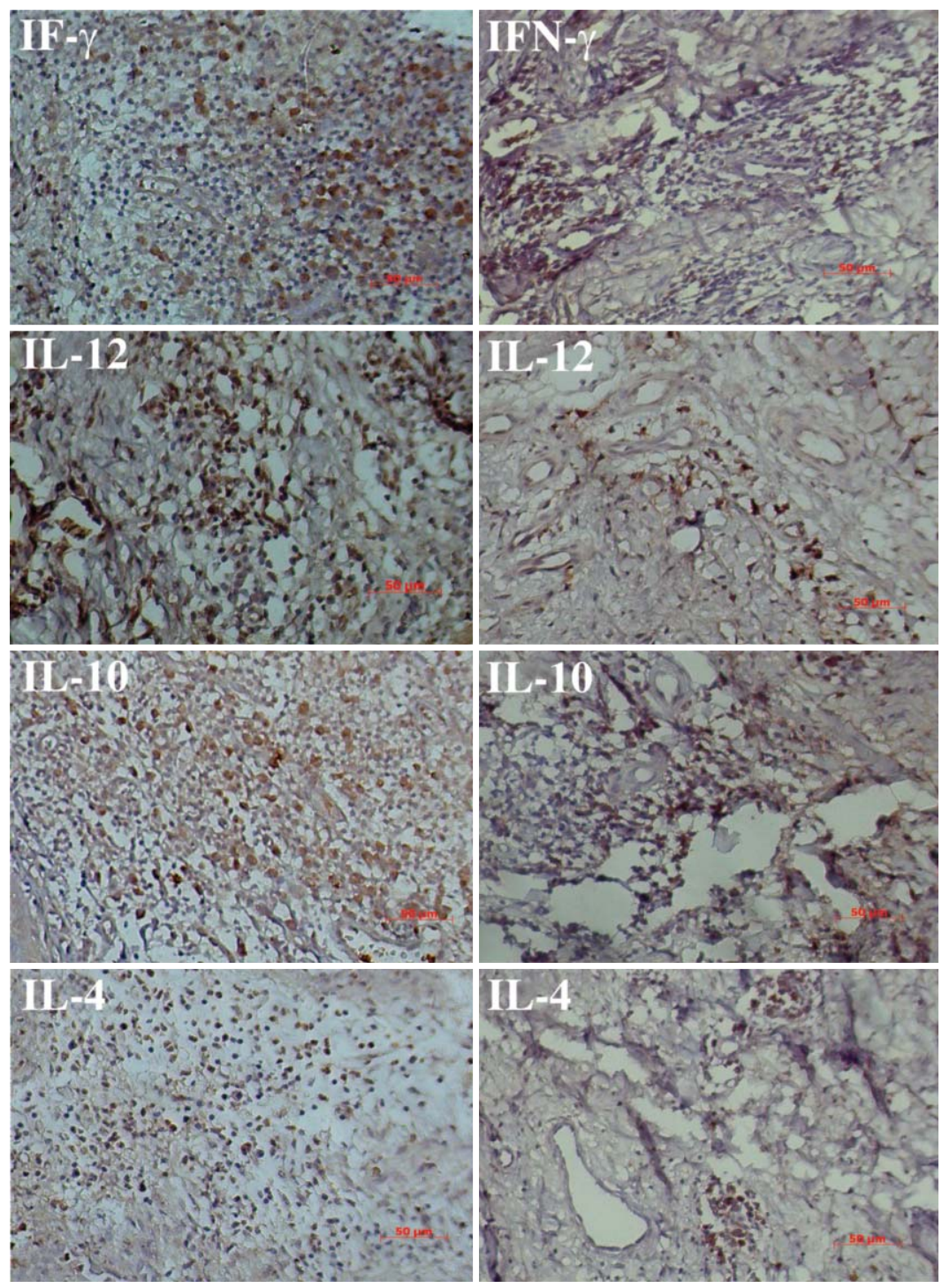

Figure 2: Expression of cytokines in cutaneous leishmaniasis and their treatments. All figures on the left is before treatment and the right side, after treatment. IFN- $\gamma$ (Glucantime), IL-12 (Leishvacin+Glucantime), IL10 (Leishvacin+Glucatime + BCG) and IL-4 (Glucantime). (Staining: DAB. Counterstained: Mayer's hematoxylin. Bar: $50 \mu \mathrm{m}$ ) clinically cured. ${ }^{17,18}$ The absence of complete resolution of the lesion suggests a persistence of the parasite antigens, which is related to the maintenance of the local inflammatory response. ${ }^{21}$ It has been suggested that sometimes immunological mechanisms are involved in the escape of the parasite. ${ }^{13}$

We demonstrated a greater expression of proinflammatory cytokines such as IFN- $\gamma$ and IL-12 in ACL samples before treatment compared to the expression of anti-inflammatory cytokines IL-10 and IL-4. Previous studies have shown that inflammatory cells in active lesions produce a high expression of IFN- $\gamma$ protein. ${ }^{22,23}$ Moreover, a high production of IL-12 seems to be important in the induction and maintenance of IFN- $\gamma$ levels. ${ }^{22} \mathrm{~A}$ high expression of IFN- $\gamma$ can result in containment of the parasite by preventing its spread. ${ }^{24}$
Analysis of the immunological profile in peripheral blood mononuclear cells (PBMC) of patients with ACL showed that the presence of anti-inflammatory cytokines such as IL- 4 and IL-10 appears to be related to the inhibition of Th1 cytokine activities, favoring induction of the Th2 response. ${ }^{13}$ Interleukin- 4 inhibits the proliferation of IFN- $\gamma$ and consequently reduces its production, thereby inducing the escape of the parasite. ${ }^{13}$ Interleukin-10 can provide a disease progression, exerting an important role in regulating the inflammatory response by inhibiting the infection control. ${ }^{25}$

The presence of IFN- $\gamma$ is synergistically linked to TNF- $\alpha$, where they activate macrophages and lead to the induction of inducible nitric oxide synthase induced (iNOS) ${ }^{23}$ Inducible nitric oxide synthase catalyzes the synthesis of nitric oxide (NO), a potent 

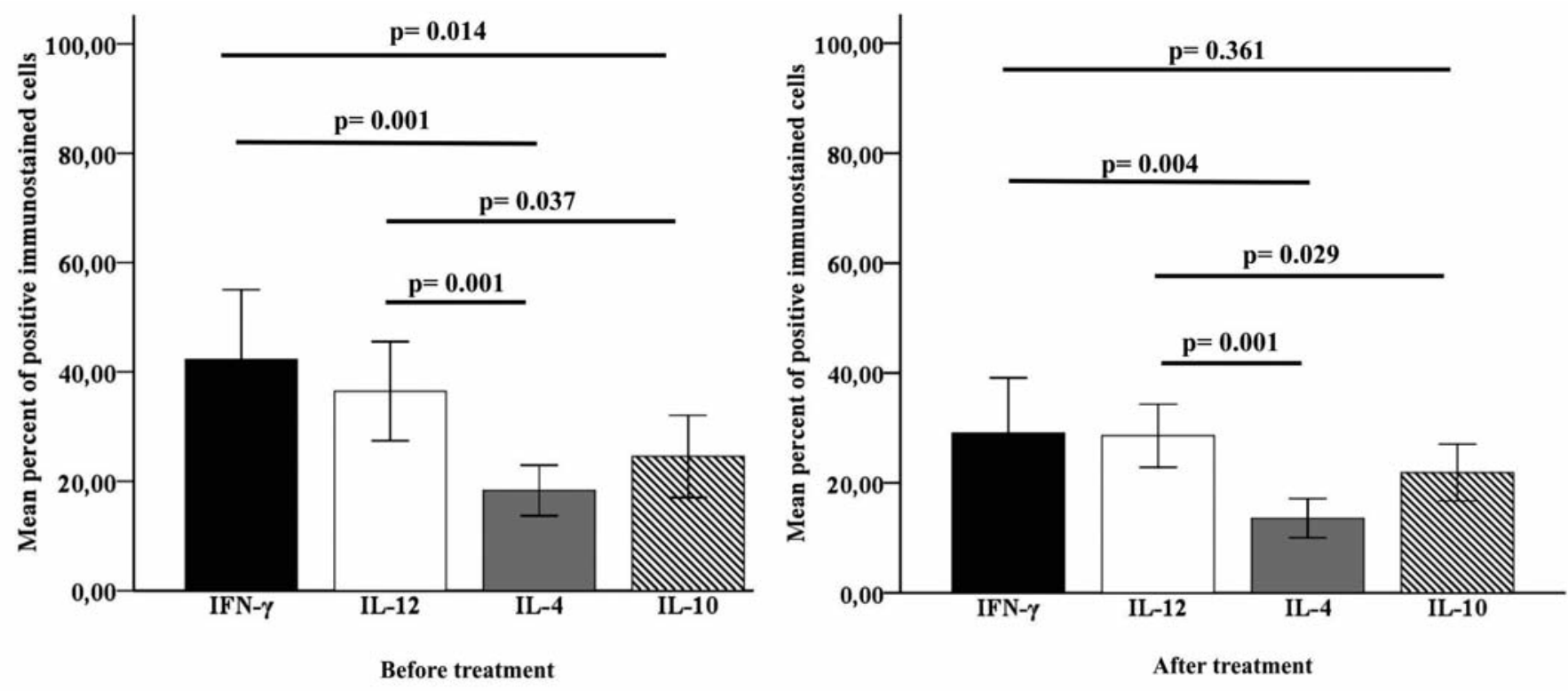

GRAPHIC 1: Average expression of cytokines of the all patients grouped regardless of treatment type, before and after treatment. There was a significant difference between cytokines $(\mathrm{p}<0,05)$, calculated using the Mann-Whitney test

microbicidal agent that leads to death of intracellular parasites. ${ }^{26,27}$ An intense iNOS expression correlates with a lower level of parasitism in patients with $\mathrm{ACL},{ }^{27}$ since a higher number of iNOS molecules correlates with a high expression of IFN- $\gamma$ and IL-12, leading to wound healing. ${ }^{26}$

In our study, we observed a mixed pattern of Th1 and Th2 immune responses via the production of cytokines. Studies have shown that the Th1 response is necessary to control the parasite and lesion healing. In contrast, cytokines of the Th2 response are involved in the escape of the parasite. ${ }^{16}$

Immunological markers appear to be associated with clinical indicators, making it possible to perceive an association between the frequency of IFN- $\gamma$ and an increase in ulceration of the lesion, indicating that an exacerbated response contributes to tissue damage. ${ }^{28}$ It is believed that in these cases the production of IL10 is usually increased by blocking the activation of the Th1 response, balancing an exaggerated response while avoiding tissue damage. ${ }^{25}$

In both histological and immunohistochemical analyzes, we did not observe a different evolution to cure with each of the treatments. The use of Leishvacin + Glucantime and Leishvacin + BCG associated with Glucantime was as effective as Glucantime, which is the first choice of treatment for ACL, even though it is a toxic drug with side effects and contraindications for cardiopathy, nephropathy, and pregnancy, among other conditions. The use of the other therapies in association with Glucantime reduced the amount of Glucantime required. Mayrink et al. found that a combination of chemotherapy and immunotherapy had the same cure rate compared to the standard treatment, and it also reduced the volume of salt used and the side effects caused. ${ }^{6}$

In our study, regardless of treatment type, we noticed that after treatment there was a decreased expression of the cytokines analyzed. In vitro studies showed that patients treated with Glucantime and Glucantime associated with Leishvacin had a high expression of IFN- $\gamma$ after treatment. It is believed that greater expression promotes a speedy elimination of Leishmania by activating macrophages. It also decreases the persistence of the lesion and protects against recurrence..$^{29}$ The process of wound healing is associated with a decreased production of IL- 4 and IL10 , cytokines that block the production of IFN- $\gamma$ and macrophage activation. ${ }^{13}$ When evaluating the effectiveness of BCG in patients, a strong IFN- $\gamma$ response was observed. BCG is known to activate the production of macrophages, TNF- $\alpha$, and nitric oxide, promoting microbicidal activity ${ }^{30}$ Increased knowledge about the immunoregulatory mechanisms involved in human disease is required for the development of therapeutic strategies. ${ }^{13}$

\section{CONCLUSION}

We conclude with the observation that the histopathological findings, presented with the clinical cure, did not show a histological pattern characteristic of ACL; the evolution of histopathological healing was 

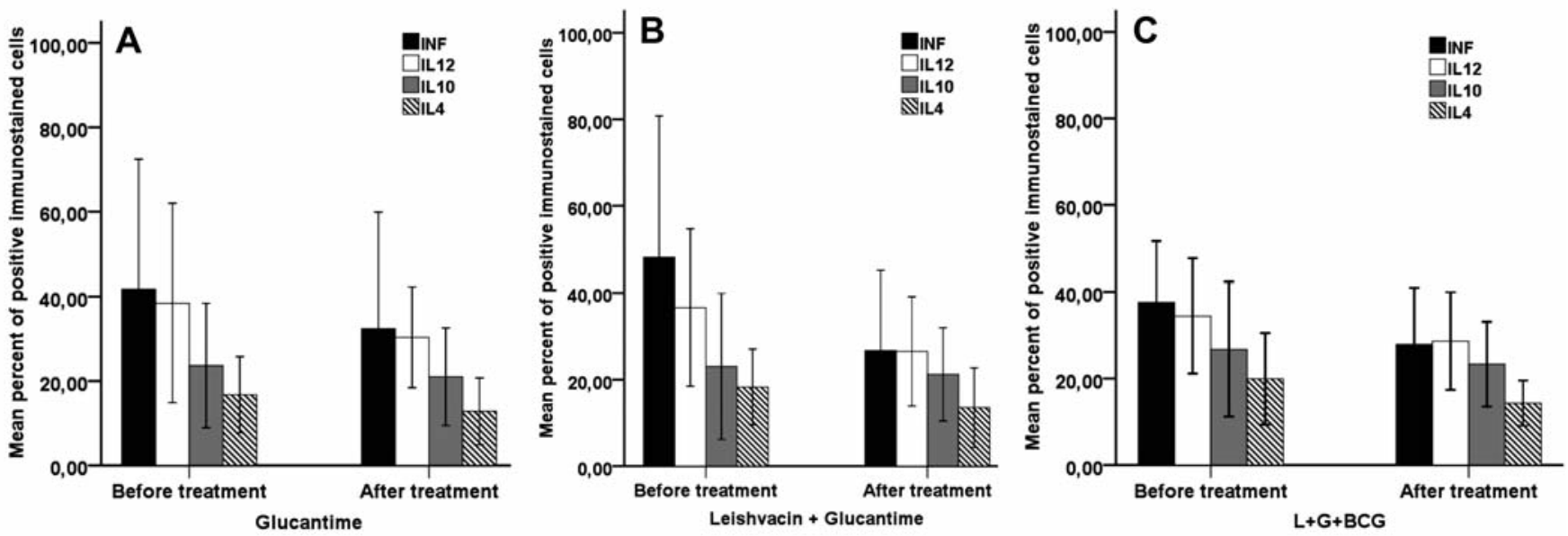

GraphIC 2: Average expression of IFN- $\gamma$, IL-12, IL-10 and IL-4 proteins in leishmanial lesions. Analyses of protein expressions before and after Glucantime (Fig. 1 A), Leishvacin + Glucantime (Fig. 1B) and Leishvacin + Glucantime + BCG (Fig. 1C) treatments. Note that there was no statistically significant difference in the expression of proteins $(\mathrm{p}>0.05)$. Values of IFN- $\gamma$, IL-12, IL- 4 and IL-10 protein expressions were calculated using the Wilcoxon test

observed in the patients, but this healing did not always coincide with clinical healing. Therefore, a criterion of cure ideal should consider aspects of clinical, histopathological, and parasitological analyses. ${ }^{16}$ The immune response before treatment showed an increased expression of Th1 cytokines, and after treatment there was a reduction in inflammatory response and a mix of cytokines of Th1 and Th2 responses. We also report that there was no statistically significant difference in the evolution of healing amongst the three treatments, indicating the equivalence in clinical cure for the three treatments, showing that ACL can be effectively treated by a combination of immunotherapy and immunochemotherapy, decreasing the amount of Glucantime required.

\section{REFERENCES}

1. Botelho ACC, Mayrink W, Oliveira RC. Alterations in phenotypic profiles of peripheral blood cells from patients with human American cutaneous leishmaniasis following treatment with an antimonial drug and a vaccine. Acta Trop. 2009:112:143-8.

2. Brasil. Ministério da Saúde. Secretaria de Vigilância em Saúde. Manual de Vigilância da Leishmaniose Tegumentar Americana. 2 ed. atual. Brasília: Editora do Ministério da Saúde; 2007.

3. World Health Organization (WHO). Report of the Fifth Consultative Meeting on Leishmania/HIV Coinfection. Addis Ababa, Ethiopia, 20-22 March 2007.

4. Gontijo CM, da Silva ES, de Fuccio MB, de Sousa MC, Pacheco RS, Dias ES, et al. Epidemiological studies of an outbreak of cutaneous leishmaniasis in the Rio Jequitinhonha Valley, Minas Gerais, Brazil. Acta Trop. 2002,81:143-50.

5. Musa AM, Noazin S, Khalil EAG, Modabber F. Immunological stimulation for the treatment of leishmaniasis: a modality worthy of serious consideration. Trans R Soc Trop Med Hyg. 2009;104:1-2.
6. Mayrink W, Botelho ACC, Magalhães PA, Batista SM, Lima AOI, Genaro 0, et al. Immunotherapy, immunochemotherapy and chemotherapy for American cutaneous leishmaniasis treatment. Rev Soc Bras Med Trop. 2006;39:14-21.

7. Bittencourt AL, Barral A. Evaluation of the histopathological classifications of American Cutaneous and mucocutaneous Leishmaniasis. Mem Inst Oswaldo Cruz. 1991;86:51-6.

8. Ventakaram M, Moosa M, Devi L. Histopathological spectrum in cutaneous leishmaniasis: A study in Oman. Indian J Dermatol Venereol Leprol. 2001;67:294-8.

9. ul Bari A, ber Rahman S. Correlation of clinical, histopathological and microbiological findings in 60 cases of cutaneous leishmaniasis. Indian J Dermatol Venereol Leprol. 2006;72:28-32.

10. Campos-Neto A. What about Th1/Th2 in cutaneous leishmaniasis vaccine discovery? Braz J Med Biol Res. 2005;38:979-84. 
11. Reis LC, Brito MEF, Souza MA, Medeiros AC, Silva CJ, Luna CF, et al. Cellular immune response profile in patients with american tegumentary leishmaniasis prior and post chemotherapy treatment. J Clin Lab Anal. 2009;23:63-9.

12. Rogers KA, Dekrey GK, Mbow ML, Gillespie RD, Brodskyn Cl, Titus RG. Type 1 and type 2 responses to Leishmania major. FEMS Microbiol Lett. 2002;209:1-7.

13. Castellano RL, Filho DC, Argiro L, Dessein H, Prata A, Dessein A, et al. Th1/Th2 immune responses are associated with active cutaneous leishmaniasis and clinical cure is associated with strong interferon production. Hum Immunol. 2009;70:383-90.

14. Mayrink W, Michalick MSM, Melo MN, Willians PA, Costa CA, Lima AO, et al Tratamento da leishmaniose tegumentar utilizando vacina. An Bras Dermatol. 1991;66:55-59.

15. Farias LC, Fraga CA, De Oliveira MV, Silva TF, Marques-Silva L, Moreira PR, et al. Effect of age on the association between p16CDKN2A methylation and DNMT3B polymorphism in head and neck carcinoma and patient survival. Int $\mathrm{J}$ Oncol. 2010;37:167-76.

16. Botelho ACC, Tafuri WL, Genaro 0, Mayrink W. Histopathology of human american cutaneous leishmaniasis before and after treatment. Rev Soc Bras Med Trop. 1998:31:11-8.

17. Botelho ACC. Análise de marcadores fenotípicos das populações celulares no exsudato inflamatório da lesão e no sangue periférico de pacientes portadores de leishmaniose tegumentar americana antes e após diferentes tratamentos [tese]. Belo Horizonte: Universidade Federal de Minas Gerais; 2004.

18. Mendonça MG, Brito MEF, Rodrigues EHG, Bandeira V, Jardim ML, Abath FG, et al. Persistence of leishmania parasites in scars after clinical cure of American cutaneos leishmaniasis: is there a sterile cure? J Infect Dis. 2004;189:1018-23.

19. Ventakaram M, Moosa Mohammed, Devi L. Histopathological spectrum in cutaneous leishmaniasis: A study in Oman. Indian J Dermatol Venereol Leprol. 2001:67:294-8.

20. Morgado FN, Schubach A, Vasconcellos E, Azeredo-Coutinho RB, Valete-Rosalino CM, Quintella LP, et al. Signs of an in situ inflamatory reaction in scars of human American tegumentary leishmaniasis. Parasite immunol. 2010;32:285-95.

21. Amato VS, de Andrade HF, Duarte MI. Mucosal leishmaniasis: in situ characterization of the host inflammatory response, before and after treatment. Acta Trop. 2003;85:39-49.
22. Meymandi S, Dabiri S, Meymandi-Shamsi M, Nikpour $H$, Kharazmi A. Immunophenotypic pattern and cytokine profiles of dry type cutaneous leishmaniasis. Arch Iranian Med. 2009;12:371-6.

23. Faria DR, Gollob KJ, Barbosa J Jr, Schriefer A, Machado PR, Lessa H, et al Decreased in situ expression of interleukin-10 receptor is correlated with the exacerbated inflammatory and cytotoxic responses observed in mucosal leishmaniasis. Infect immune. 2005;73:7853-9

24. Vieira MG, Oliveira F, Arruda S, Bittencourt AL, Barbosa AA Jr, Barral-Netto M, et al. $B$-cell infiltration and frequency of cytokine producing cells differ between localized and disseminated human cutaneous leishmaniases. Mem Inst Oswaldo Cruz. 2002;97:979-83

25. Gomes-Silva A, de Cássia Bittar R, Dos Santos Nogueira R, Amato VS, da Silva Mattos M, Oliveira-Neto MP, et al. Can interferon- $\gamma$ and interleukin-10 balance be associated with severity of human Leishmania (Viannia) braziliensis infection? Clin Exp Immunol. 2007;149:440-4.

26. Díaz NL, Arveláez FA, Zerpa 0, Tapia FJ. Inducible nitric oxide synthase and cytokine pattern in lesionsof patients with American cutaneous leishmaniasis. Clin Exp Dermatol. 2006;31(1):114-117.

27. Qadoumi M, Becker I, Donhauser N, Röllinghoff M, Bogdan C. Expression of inducible nitric oxide synthase in skin lesions of patients with American cutaneous leishmaniasis. Infect Immun. 2002;70:4638-42.

28. Antonelli LRV, Dutra WO, Almeida RP, Bacellar 0, Carvalho EM, Gollob KJ. Activated inflammatory T cells correlate with lesion size in human cutaneous leishmaniasis. Immunol Lett. 2005;101:226-30.

29. Toledo VPCP, Mayrink W, Gollob KJ, Oliveira MAP, da Costa CA, Genaro 0, et al. Immunotherapy in American Cutaneous Leishmaniasis: Immunological Aspects before and after Treatment. Mem Inst Oswaldo Cruz. 2001;96:89-98.

30. Cabrera M, Blackwell JM, Castes M, Trujillo D, Convit J, Shaw MA. Immunotherapy with live BCG plus heat killed Leishmania induces a T helper 1-like response in American cutaneous leishmaniasis patients. Parasite Immunol. 2000;22:73-9.

\author{
MAILING ADDRESS: \\ Ana Cristina de Carvalbo Botelbo \\ Av. Cula Mangabeira, 562, \\ Santo Expedito \\ 39401-002 Montes Claros, MG \\ E-mail: anacristina.botelbo@yaboo.com.br
}

How to cite this article: Viana AG, Mayrink W, Fraga CAC, Silva LM, Domingos PLB, Bonan PRF, De-Paula AMB, Botelho ACC. Histopathological and immunohistochemical aspects of American cutaneous leishmaniasis before and after different treatments. An Bras Dermatol. 2013;88(1):32-40. 